IZA DP No. 4746

Intrinsic Motivations and the Non-Profit Health Sector: Evidence from Ethiopia

Danila Serra

Pieter Serneels

Abigail Barr

February 2010 


\title{
Intrinsic Motivations and the Non-Profit Health Sector: Evidence from Ethiopia
}

\author{
Danila Serra \\ Florida State University \\ Pieter Serneels \\ University of East Anglia \\ and IZA
}

Abigail Barr

University of Oxford

\section{Discussion Paper No. 4746 \\ February 2010}

\author{
IZA \\ P.O. Box 7240 \\ 53072 Bonn \\ Germany \\ Phone: +49-228-3894-0 \\ Fax: +49-228-3894-180 \\ E-mail: iza@iza.org
}

\begin{abstract}
Any opinions expressed here are those of the author(s) and not those of IZA. Research published in this series may include views on policy, but the institute itself takes no institutional policy positions.

The Institute for the Study of Labor (IZA) in Bonn is a local and virtual international research center and a place of communication between science, politics and business. IZA is an independent nonprofit organization supported by Deutsche Post Foundation. The center is associated with the University of Bonn and offers a stimulating research environment through its international network, workshops and conferences, data service, project support, research visits and doctoral program. IZA engages in (i) original and internationally competitive research in all fields of labor economics, (ii) development of policy concepts, and (iii) dissemination of research results and concepts to the interested public.
\end{abstract}

IZA Discussion Papers often represent preliminary work and are circulated to encourage discussion. Citation of such a paper should account for its provisional character. A revised version may be available directly from the author. 
IZA Discussion Paper No. 4746

February 2010

\section{ABSTRACT \\ Intrinsic Motivations and the Non-Profit Health Sector: Evidence from Ethiopia}

Economists have traditionally assumed that individual behavior is motivated exclusively by extrinsic incentives. Social psychologists, in contrast, stress that intrinsic motivations are also important. In recent work, economic theorists have started to build psychological factors, like intrinsic motivations, into their models. Besley and Ghatak (2005) propose that individuals are differently motivated in that they have different "missions," and their self-selection into sectors or organizations with matching missions enhances organizational efficiency. We test Besley and Ghatak's model using data from a unique cohort study. We generate two proxies for intrinsic motivations: a survey-based measure of the health professionals' philanthropic motivations and an experimental measure of their pro-social motivations. We find that both proxies predict health professionals' decision to work in the non-profit sector. We also find that philanthropic health workers employed in the non-profit sector earn lower wages than their colleagues.

JEL Classification: C93, I11, J24

Keywords: $\quad$ sector choice, intrinsic motivation, non-profit

Corresponding author:

Danila Serra

Florida State University

Department of Economics

258 Bellamy

Tallahassee, FL 32301

USA

E-mail: dserra@fsu.edu 


\section{Introduction}

According to social psychologists an individual performing whatever act will look for two kinds of justifying rationale: extrinsic incentives and intrinsic motivations. Edward L. Deci (1975) wrote that "one is said to be intrinsically motivated to perform an activity when one receives no apparent reward except the activity itself”. Economists rarely account for intrinsic motivations, although recently some have started building them into theoretical models and investigating them experimentally. ${ }^{1}$

Intrinsic motivations may be especially relevant in social service, particularly in teaching and healthcare, both traditionally described as vocations. Delfgauuw and Dur (2008), Prendergast (2007) and Francois (2000) have shown that intrinsically motivated public service providers exert more effort and require fewer extrinsic incentives than self-interested providers. Besley and Ghatak (2005) (B\&G) propose an alternative perspective in which both workers and organizations vary with respect to their missions; one sector of an economy might be oriented towards standard profitmaximization, another towards philanthropic endeavours, a third towards social efficiency and functionality, a fourth towards beauty and the arts, and so on. B\&G show that mission diversity within a society enhances productivity through the matching of employers and employees with similar missions.

Our paper empirically explores whether, in the spirit of $B \& G$, young, Ethiopian, philanthropically or pro-socially motivated health professionals self-select into the non-profit sector as opposed to the public and for-profit sectors and whether mission-matching increases organizational efficiency. At first glance it may seem odd

\footnotetext{
${ }^{1}$ Fehr and Schmidt (2006) provide an extensive review of the experimental literature on non-monetary motives driving human behavior in a number of situations.
} 
that we group the public health sector with the private for-profit sector rather than the non-profit sector. In principle, we would expect the public sector and public servants to be motivated by the notion of public service, a mission that, especially in a poor country, seems closer to pro-sociality and philanthropy than profit maximization. However, in Ethiopia, the original mission of the public sector, to provide adequate health services to all segments of the population, has been eroded by decades of central planning, weak monetary incentives and poor accountability, leading to widespread opportunism on the part of public healthcare providers (see Lindelow and Serneels, 2006).

Measuring pro-social and philanthropic motivations is challenging. Proxies have been derived from individuals' responses to specially designed survey questions, ${ }^{2}$ but these can be susceptible to response bias. An alternative approach relies on observing individuals' actual choices ('revealed preferences'). Gregg et al. (2007), for instance, measure such motivations as the number of unpaid extra hours of work. They find that workers in the British non-profit and public sectors "donate" more labor than those in the for-profit sector and that this is primarily due to selection. However, the validity of this approach depends on our willingness to accept unpaid extra hours worked as a proxy for pro-social or philanthropic motivations.

Here, we use a survey-based measure and a measure derived using a third, to date untested, approach: we use an economic experiment to measure individual prosociality in a controlled environment. ${ }^{3}$

Our results provide support for B\&G's theory. Both of our motivational proxies predict working in the non-profit sector. The results also support the

\footnotetext{
${ }^{2}$ The public administration literature provide examples of survey-based multi item proxies of "public service motivation”. See Perry (1996) for details.

${ }^{3}$ For a recent discussion of the application of laboratory experiments to the social sciences see Falk and Heckman (2009).
} 
prediction that mission matching "economizes on the need for high-powered extrinsic incentives” (B\&G, p.616) as we find evidence that non-profit employers pay lower salaries to philanthropically motivated health workers, reserving higher salaries for more competent health workers.

Further analysis shows that controlling for whether a health worker received his or her medical education at a non-profit-run college suppresses the pro-social and philanthropic motivation results, suggesting that the mission-matching may actually occur at college entry or that colleges socialize individuals into different missions and that, either way, employers know that the type of college attended relates to individual motivations.

The paper has six sections. Section 2 reviews the literature on motivations and the non-profit sector and introduces the Ethiopian context. Section 3 describes our data, including our proxies for philanthropic motivations. Section 4 presents our empirical results. Finally, Section 5 summarizes and concludes.

\section{Intrinsic motivations and the non-profit sector}

\subsection{The non-profit sector}

There are three important institutional differences between non-profit and forprofit firms: 1) non-profit firms need donations for their initial equity capital, 2) they cannot distribute revenues in the form of cash dividends, and 3) they cannot be liquidated for proceeds to be paid to the firms’ owners (Pauly, 1987). The exclusion of profit-maximization from the objectives of non-profit firms raises questions about why they exist and why the sector has grown so rapidly in both developed and 
developing countries. Susan Rose-Ackerman (1996) suggests three possible answers: trust, generosity and ideology. Trust and generosity come into play when customers and donors have imperfect information about service quality: in these settings, knowledge of the inability of the owners to expropriate revenues may drive customers and donors towards the non-profit sector. ${ }^{4}$ Ideology refers to non-profit entrepreneurs who have a mission other than profit-maximization and want to operate without being held accountable to profit-seeking investors. However, non-profit entrepreneurs do not need to be ideologically motivated; if they are not, ex-ante soft incentives may lead to ex-post opportunistic behaviour, resulting in "for-profits in disguise". ${ }^{5}$ While the non-profit sector does not require a pro-social or philanthropic mission in order to exist, a subsector, namely the NGO sector, does. ${ }^{6}$

The John Hopkins Center for Civil Society Studies has documented the NGO sectors of several high income countries. NGOs in developing countries, especially in Africa, have received less attention, although Leonard (2002) reports on the wide diffusion of NGO health providers in Ghana, Tanzania and Zimbabwe. In Zimbabwe, for instance, NGOs provide 35 percent of all hospital beds; moreover, 95 percent of the NGOs facilities are located in rural areas, suggesting a strong commitment to reach those most in need. Reinnika and Svensson (2008) analyze the role of intrinsic motivations to serve the poor among religious non-profit health care providers in Uganda

\footnotetext{
${ }^{4}$ Asymmetric information plays a crucial role especially in the provision of health care. See Arrow (1963).

${ }^{5}$ See Glaeser and Shleifer (2001) for a recent theoretical analysis of the possible motives of nonprofit entrepreneurs. Barr, Fafchamps and Owens (2004) link this to accountability and provide unique evidence for the Ugandan non-profit sector.

${ }^{6}$ We use the terms non-profit, and NGO interchangeable in this paper, since the Ethiopian health nonprofit sector exists overwhelmingly of NGOs.
} 


\subsection{The Ethiopian context}

Ethiopia ranks among the worst countries in the world in terms of health service coverage and health outcomes. ${ }^{7}$ Per capita health expenditures are approximately 25 USD PPP, which is significantly lower than the Sub-Sahara Africa average of 89 USD PPP (World Bank 2004). The number of health workers per capita - 11 nurses and 2 physicians per 100,000 inhabitants - remains extremely low even by African standards.

As in most low income countries, the Ethiopian health sector is dominated by the public sector: in our data $73 \%$ of nurses and $82 \%$ of doctors work for the public sector. However, both the for-profit and non-profit sectors are growing. The estimated number of NGOs working in Ethiopia exceeds 3000, is rising, and includes a majority involved in health care. ${ }^{8}$

As elsewhere, organizations in the public, for-profit and non-profit sectors have very different missions. The for-profit sector aims to maximize profits by providing healthcare to those able to pay. The formal aim of the public sector is to provide health care to all Ethiopians, ${ }^{9}$ although this mission has been eroded by decades of central planning, weak monetary incentives in the form of low wages and poor accountability due to inadequate or inexistent monitoring and enforcement mechanisms. The current commonly held perception of the public health sector in Ethiopia incorporates long waiting times, under-the-table payments, absenteeism and moonlighting (Lindelow and Serneels, 2006). In contrast, the non-profit sector has a

\footnotetext{
${ }^{7}$ For a detailed discussion of health outcomes and the Ethiopian health system more broadly, see World Bank (2004).

${ }^{8}$ See http://www.crdaethiopia.org

${ }^{9}$ The Ministry of Health states its mission as follows: "to improve the health status of the Ethiopian people through provision of adequate and optimum quality of promotive, preventive, basic curative and rehabilitative health services to all segments of the population.”
} 
good reputation. Its mission is to serve the poor and vulnerable. The mission statements of the NGOs in our sample include statements such as "improve the lives of the most vulnerable people", "reach out to vulnerable populations", and "combat the root causes of poverty." And consistent with this mission, almost half of the NGOs in our sample operate in rural areas, where the poorest Ethiopians live. In our sample, only 24 and 26 percent of private-for-profit and public sector health facilities respectively operate in rural areas.

\section{The Data}

We use data from the Ethiopian Health Workers Cohort Survey. The first wave was conducted in spring 2004 and involved 219 nursing and 90 medical students, sampled from eight clinical nursing colleges and three medical faculties country-wide. The nursing students were in the final year of their training while the medical students were about to enter the one-year internship, which precedes graduation. ${ }^{10}$ Three years later, the same individuals, by then in paid employment, were resurveyed. Our sample represents $49 \%$ of the 2003/4 cohort of medical students, and an estimated $16 \%$ of the $2003 / 4$ cohort of nursing students. In the second wave $80 \%$ of the nurses and $98 \%$ of the medical doctors were traced, giving rise to panel data for 177 nurses and 88 doctors. Table 1 presents descriptive statistics for these 227 health professionals with complete data, at the time of the first interview.

Table 1 shows that close to 20 percent of the nurses currently work in a nonprofit facility. The proportion of doctors employed in the non-profit sector is significantly lower, at 6 per cent. The net earnings of nurses, i.e., the sum of their

\footnotetext{
${ }^{10}$ Details on the sampling strategy the follow-up process can be found in Serra et al (2010).
} 
salaries and benefits, are highest in the non-profit sector. However, on average, nurses employed in the non-profit sector work one additional hour per day compared to nurses employed in the other two sectors (difference statistically significant at 1 percent level). As a consequence, the non-profit sector pays nurses slightly but not significantly lower hourly wages compared to the other sectors. In contrast, doctors earn most and work the longest hours when employed in the for-profit sector.

Table 1 also reports the health workers' performance in a test taken during the first wave of the survey. ${ }^{11}$ We use the test scores as a measure of competence. On average, nurses in the non-profit sector are more competent than their colleagues in the private for-profit sector and less competent than those in the public sector, although the differences are statistically insignificant. Test scores for doctors are also not significantly different across sectors.

\subsection{Survey-based proxy for philanthropic motivation}

In the first wave survey the students were asked to rank eight job characteristics according to their importance to them; “opportunity to help the poor" was among the job characteristics. Figure 1 shows that 13 percent of the doctors and 34 percent of the nurses ranked "opportunity to help the poor" as the most important job characteristic. In our analysis below we use an indicator variable that takes the value of one when "opportunity to help the poor" is given first place in the ranking. However, we acknowledge that individuals’ concerns about their own ideal self-image

\footnotetext{
${ }^{11}$ To ensure that it took the curriculum and Ethiopian conditions into account, the test was prepared by a team from Addis Ababa University who teach nursing and medicine. For more details about the test see Serneels et al (2004)..
} 
- the values or identities that they would like to portray - may have influenced the way they responded to this question. ${ }^{12}$

\subsection{Experimentally derived proxy for pro-sociality}

During the first wave of the Cohort Survey, we asked the youngsters to participate in a Generalized Trust Game (GTG). In the game, initially designed by Buchan, Crosson, and Dawes (2002), a Proposer decides how much (zero to 100 percent) of her initial cash endowment to send to a Responder, the amount she sends is tripled by the experimenter before being passed to the Responder who also receives the same initial endowment; then, the Responder is invited to send some portion (zero to 100 percent) of the tripled amount to some other Proposer present in the same session. In Ethiopia, the Proposers and Responders' initial endowments were set at Birr 40 and each player could send multiples of Birr 10. Proposers made their decision by dividing their initial endowment between two envelopes. Responders had to fill out a form stating what they would do in the case of each possible amount sent to them, before seeing the actual amount sent. This use of the strategy elicitation method ensured perfect comparability across Responders.

We chose the GTG because the decision made by Responders is conceptually close to the day-to-day decisions made by health workers; they receive resources, which they are expected to pass on to others. So, we assigned our survey responders to the role of Responder and recruited additional youngsters from the same colleges to assume the Sender role. ${ }^{13}$

\footnotetext{
12 Johansson-Stenman and Martinsson (2003), for instance, report significant differences in individuals' answers when asked about the attributes that they preferred in a car (most answered "environmental performance") and those preferred by their neighbours ( most answered "social status".)

${ }^{13}$ Each medical and nursing student attended an experimental session at their college. A total of 20 sessions were held, with between 29 and 60 students attending each. All 20 sessions were led by the
} 
Below, we use the sum of the four amounts returned by each Responder divided by the sum of the four amounts that could have been sent to each Responder as a measure of their willingness to pass on resources entrusted to them. Figure 2 presents a histogram of these ratios. There is a strong mode at one; 20 percent of the students chose to pass on the amount that had been entrusted to them, while keeping twice that amount for themselves. Just over ten percent chose to pass on nothing. Just under ten percent chose to pass on twice the amount entrusted to them. On average, the students chose to return slightly more than the amount sent, while keeping almost twice that amount for themselves.

\subsection{Comparing the two measures of intrinsic motivations}

Our two measures of intrinsic motivations have different strengths and weaknesses. The survey measure, designed to capture the health workers' desire to provide health care to those most in need, has high apparent salience but may be subject to response bias. The experimental measure, designed to capture the health workers' willingness to pass on resources entrusted to them for the greater good, is likely to be free of response bias but might not be so salient.

The two measures have a low and insignificant coefficient of correlation (coefficient $=0.05, \mathrm{p}=0.36$ ) suggesting that they do indeed capture different motivations.

same team comprised of one of the authors and three Ethiopian assistants, who translated into Amharic where needed. For further details see Serneels et al. (2004). 


\section{Empirical Analysis}

\subsection{Econometric strategy}

To investigate the role of pro-social and philanthropic motivations in the career choices of health professionals, we estimate the following equation:

$$
L_{i}=\beta_{0}+\beta_{1} \text { HELPPOOR }_{i}+\beta_{2} \text { MEANRET }_{i}+\beta_{3} \text { TEST }_{i}+\beta_{4} X_{i}+\beta_{7} \text { DOCTOR }_{i}
$$

where $L_{i}$ is the labor outcome of interest; HELPPOOR is our survey proxy for philanthropic motivations; MEANRET is the experimental proxy for pro-social motivations; TEST is the test-score measure of competence; $X$ contains demographic variables like age, gender and marital status; DOCTOR equals one for doctors and zero otherwise. We estimate a Probit to model sector choice and an OLS regression to model their earnings.

\subsection{Empirical results}

Table 2 reports several Probit estimations each taking a dummy equal to one if the health worker is employed in the non-profit sector and zero otherwise as the dependent variable. Columns 1 to 3 indicate that both motivational proxies are significantly associated with choosing to work in the non-profit sector. Column 4 shows that this result is robust to controlling for competence and individual characteristics. The coefficients on the motivational proxies are large. An individual who ranked 'help the poor' as most important was 12 percent more likely to be 
working in the non-profit sector. And an individual who, on average, passed on fifty percent more than he or she received in the GTG game was 5 percent more likely to be working in the non-profit sector than an individual who, on average, passed on fifty percent less than he or she received. ${ }^{14}$

When, in Column 5, we control for whether the health workers graduated from a non-profit-run college, this suppresses the motivation-related results. ${ }^{15}$ This last finding has three possible interpretations. Since, in our data, graduates from nonprofit-run colleges are significantly more philanthropically and pro-socially motivated, being a graduate from an non-profit-run college may serve as a signal for intrinsic motivations during the recruitment process. This may occur because nonprofit-run colleges may cause individuals to become more pro-social and philanthropic, or because mission matching may occur at the point of college entry. However, we cannot exclude a third explanation: there may be some other reason, unrelated to philanthropic and pro-social motivations, why graduates of non-profit-run colleges select to work in the non-profit sector. We shall return to this point below.

Turning to hourly earnings, in Table 3, we find, in Column 1, that, in accordance with the theory, there are no monetary returns to pro-social or philanthropic motivations.

The second and third column of Table 3 suggest that the non-profit sector pays higher salaries than the other sectors. This seems to contradict the prediction of lower salaries in the presence of mission-matching. However, the estimates in Column 4 indicate that the non-profit sector pays lower salaries to health workers who are philanthropically motivated and higher salaries to those who are not.

\footnotetext{
${ }^{14}$ Modelling the choice between the non-profit, public and for-profit sectors using a multinomial Probit generates similar marginal effects. Results can be obtained from the authors upon request. ${ }^{15}$. Including a full set of college dummies, causes some observations to be dropped and leads to an only marginally better fit.
} 
Columns 5, 6 and 7 show that this finding is robust to the inclusion of three additional variables: one, TESTxNGO, that controls for whether the non-profit sector pays higher wages to more competent individuals; one, NGO college, that controls for graduates from non-profit-run colleges earning more or less in any sector; and one, NGO college x NGO, that controls for graduates from non-profit-run colleges earning more or less in the non-profit sector. In Columns 5 and 6, the first of these three additional variables bears a significant positive coefficient, indicating that the nonprofit sector rewards competence with higher pay. The coefficient declines in size and becomes insignificant in Column 7, possibly due to the multicollinearity associated with including additional interaction terms.

The robustness of the finding that the non-profit sector pays philanthropically motivated individuals less than individuals who are not philanthropically motivated is important for two reasons. First, it directly supports B\&G's theory. Second, it goes some way to ruling out the third explanation as to why the motivation variables become insignificant in the selection Probit when the NGO-college-dummy is also included. If, all other things being equal, philanthropic individuals are willing to work for non-profit organizations for less pay than individuals who are not philanthropic, then it seems highly likely that non-profit organizations will wish to employ the philanthropic. Building on this, it seems highly likely that the superior predictive power of the NGO college dummy in the selection estimations is because non-profit organizations believe that graduates of non-profit-run colleges are more likely to be philanthropic.

To summarize, non-profit health facilities pay philanthropically motivated health workers less than they pay other health workers, but are more likely, than for- 
profit and public health facilities, to attract philanthropically motivated employees nevertheless.

\section{Summary and conclusions}

While economists have traditionally focused on the role of extrinsic incentives for decision making, social psychologists have emphasized the role of intrinsic motivations. Over the last decade, economists have become more appreciative of the role of psychological factors in decision-making and have started to integrate them into their models. In this paper we empirically investigates the role that intrinsic motivations play when young Ethiopian health workers are making career choices. More specifically, we investigate whether, in accordance with Besley and Ghatak (2005)'s theory of mission-matching, pro-social and philanthropic health professionals select the non-profit sector as opposed to the public and private forprofit sectors.

We find evidence that philanthropically and pro-socially motivated health professionals are more likely to work in the non-profit sector as opposed to the public and the for-profit sectors. We also find evidence that non-profit employers pay philanthropically motivated health professionals lower wages than they pay health professionals who are not philanthropically motivated. The strength of the second finding lends additional support to the first and this, in turn, leads us to conclude that

non-profit employers use attendance at a non-profit-run college as a sign of philanthropic and, possibly, pro-social motivations. This is appropriate as non-profit- 
run college graduates are indeed more philanthropic and pro-social than other graduates.

Future investigations into the origins and the evolution of intrinsic motivations would be extremely valuable, as most countries, like Ethiopia, face the challenge to provide health care within stringent budget constraints. If intrinsic motivations are internalized through education and socialization, interventions that build intrinsic motivations among medical and nursing students may be an effective way forward. If, on the other hand, motivations are formed at an early age and constitute individuals’ personality traits, policies should aim at improving mission-matching between employers and employees.

\section{References}

Arrow, K. J. (1963) "Uncertainty and the welfare economics of medical care", American Economic Review, 53(5): 941 - 973.

Barr, A., M. Fafchamps and T. Owens (2005) “The governance of non-governmental organizations in Uganda”, World Development, Vol. 33 (4): 657 - 679.

Besley, T. and M. Ghatak (2005) “Competition and incentives with motivated agents”, American Economic Review, 95 (3), 616 - 636.

Buchan, N. R., R. T. A. Croson, R. M. Dawes (2002) 'Swift Neighbors and persistent strangers: A cross-cultural investigation of trust and reciprocity in social exchange’ American Journal of Sociology, 108(1): 168-206.

Deci, E. L. (1975) Intrinsic motivation, New York, Plenum Press. 
Delfgauuw, J. And R. Dur (2008) “Incentives and workers' motivation in the public sector”, Economic Journal 118: 171 - 191.

Falk, A. and J. Heckman (2009) “Lab Experiments Are a Major Source of Knowledge in the Social Sciences”, Science, 23 October 2009.

Fehr E. and K. M. Schmidt (2006) “The economics of fairness, reciprocity and altruism - Experimental evidence and new theories”, in the Handbook of the Economics of Giving, Altruism and Reciprocity,, S. Kolm and J.M. Ythier eds., Elsevier.

Francois, P. (2000) "Public service motivation as an argument for government provision,” Journal of Public Economics, 78(3), 275 - 299.

Glaeser E.L. and A. Shleifer (2001) “Not-for-profit entrepreneurs,” Journal of Public Economics, Vol. 81 (1): 99-115.

Gregg, P., Grout, P., Ratcliffe, A., Smith, S. and F. Windmeijer (2008) "How important is pro-social behavior in the delivery of public services?” CMPO Working Paper No. 08/197, University of Bristol.

Johansson-Stenman, O. and P. Martinsson (2006) "Honestly, why are you driving a BMW?” Journal of Economic Behavior and Organization, 60, 129-146.

Leonard, K. L. (2002) "When both states and markets fail: asymmetric information and the role of NGOs in African health care,” International Review of Law and Economics 22: 61-80.

Leonard K.L.. D. Masatu, A. Vialou, 2007, “Getting doctors to do their best: the roles of ability and motivation in health care quality”, Journal of Human Resources, 43 (2)

Lindelow M. and Serneels P. (2006) "The Performance of Health Workers in Ethiopia,” Social Science and Medicine, 62 (9), 2225-2235. 
Perry, J.L. (1996) “Measuring public sector motivation: An assessment of construct reliability and validity”, Journal of Public Administration Research and Theory, 6: $5-22$.

Prendergast, C. (2007) “The motivation and bias of bureaucrats”, American Economic Review, 97 (1): 180 - 196.

Reinikka R. and J. Svensson (2008) “Working for God? Evaluating service delivery of (religious) not-for-profit health facilities in Uganda”, Journal of the European Economic Association (forthcoming).

Rose-Ackerman, S. (1996) “Altruism, nonprofits and economic theory”, Journal of Economic Literature, Vol.34: 701-728.

Serneels, P., Lindelow, M., Montalvo, J. G. and A. Barr (2007) “For public service or money: Understanding geographical imbalances in the health workforce”, Health Policy and Planning 22: 128 - 138.

Serneels P., M. Lindelow, J.G.Montalvo, A.Barr (2004) An Honorable Calling? Results from a Survey with Final Year Nursing and Medical Students in Ethiopia, The World Bank.

Serra D., P.Serneels and M.Lindelow (2010) Discovering the Real World - Health Workers’ Early Work Experience and Career Preferences in Ethiopia, The World Bank, forthcoming.

World Bank (2004). The Millennium Development Goals for health: rising to the challenges. Washington, DC: World Bank. 
Figures and Tables

Figure 1: The most important job characteristic

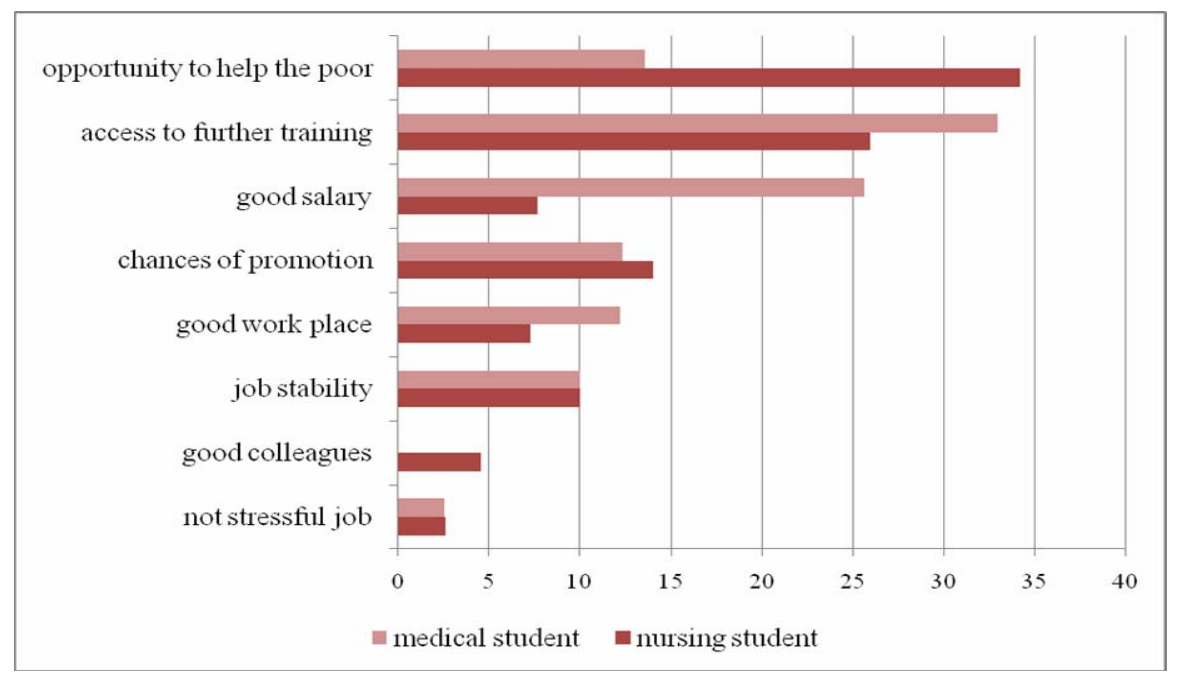

Figure 2: Histogram of mean return in generalised trust game

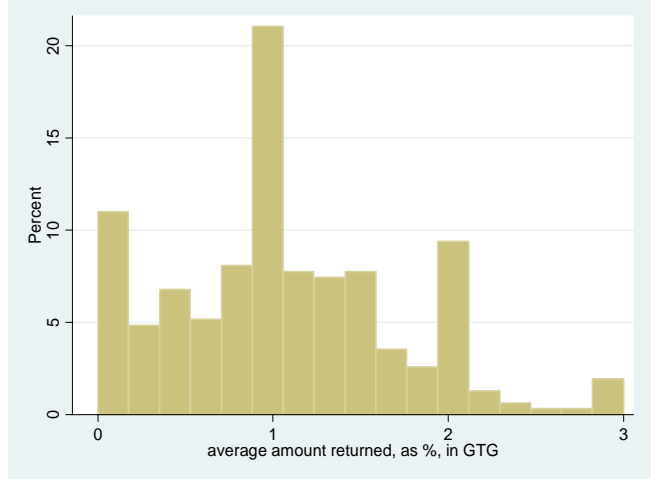

Figure 3: density of log of hourly wages

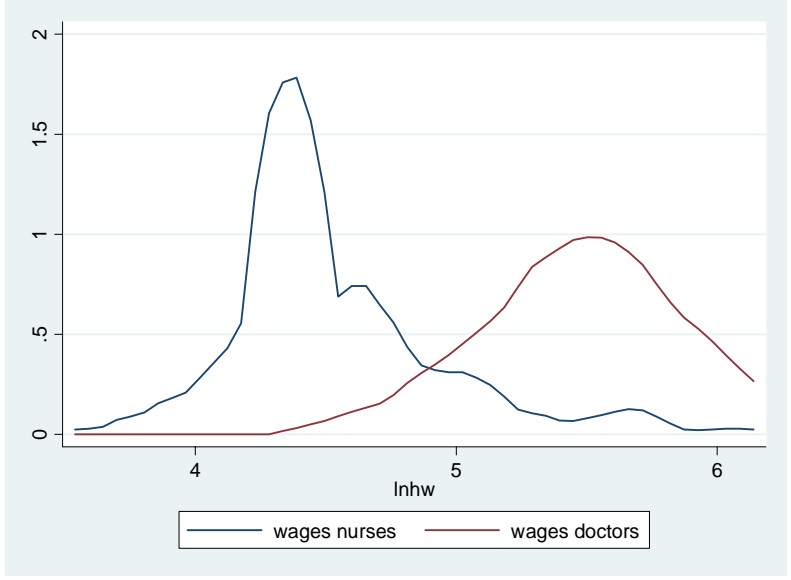


Table 1:

Student characteristics

\begin{tabular}{|c|c|c|c|c|}
\hline & \multicolumn{2}{|c|}{ Nurses } & \multicolumn{2}{|c|}{ Doctors } \\
\hline & $\begin{array}{c}\text { Mean or } \\
\text { proportion }\end{array}$ & $\begin{array}{l}\text { Standard } \\
\text { Deviation }\end{array}$ & $\begin{array}{c}\text { Mean or } \\
\text { proportion }\end{array}$ & $\begin{array}{l}\text { Standard } \\
\text { Deviation }\end{array}$ \\
\hline \multicolumn{5}{|l|}{ Personal characteristics } \\
\hline Age in 2004 (years) & 22.32 & 3.26 & 23.34 & 1.53 \\
\hline Female & 0.51 & 0.50 & 0.14 & 0.35 \\
\hline married & 0.10 & 0.30 & 0.04 & 0.21 \\
\hline help the poor & 0.28 & 0.45 & 0.14 & 0.35 \\
\hline mean return in Generalized Trust Game & 1.02 & 0.70 & 1.19 & 0.58 \\
\hline attended NGO college & 0.21 & 0.41 & - & - \\
\hline \multicolumn{5}{|l|}{ sector of work } \\
\hline private for profit sector & 0.07 & & 0.12 & \\
\hline public sector & 0.73 & & 0.82 & \\
\hline NGO sector & 0.19 & & 0.06 & \\
\hline \multicolumn{5}{|l|}{ net monthly wage } \\
\hline private for profit sector & 1163 & 632 & 4677 & 1770 \\
\hline public sector & 723 & 221 & 2050 & 533 \\
\hline NGO sector & 1352 & 959 & 4279 & 2088 \\
\hline \multicolumn{5}{|l|}{ working hours per day } \\
\hline private for profit sector & 8.45 & 1.21 & 10 & 2.21 \\
\hline public sector & 8.57 & 1.60 & 9.13 & 2.62 \\
\hline NGO sector & 9.47 & 2.21 & 9 & 1.73 \\
\hline \multicolumn{5}{|l|}{ ln(hourly wage) } \\
\hline private for profit sector & 4.85 & 0.37 & 6.11 & 0.33 \\
\hline public sector & 4.42 & 0.28 & 5.41 & 0.36 \\
\hline NGO sector & 4.82 & 0.58 & 6.09 & 0.51 \\
\hline \multicolumn{5}{|l|}{ competence as measured by test score } \\
\hline private for profit sector & 0.36 & 0.11 & 0.64 & 0.06 \\
\hline public sector & 0.43 & 0.08 & 0.61 & 0.07 \\
\hline NGO sector & 0.40 & 0.09 & 0.61 & 0.04 \\
\hline number of observations & 143 & & 84 & \\
\hline
\end{tabular}


Table 2:

Sector choice and intrinsic motivation

\begin{tabular}{|c|c|c|c|c|c|}
\hline & \multicolumn{5}{|c|}{$\begin{array}{l}\text { Dependent variable: } \\
\text { Dummy equal to } 1 \text { if the health professional works in an NGO facility }\end{array}$} \\
\hline & (1) & (2) & (3) & (4) & (5) \\
\hline HELPPOOR & $\begin{array}{c}0.14^{* *} \\
(0.06)\end{array}$ & & $\begin{array}{l}0.12 * * \\
(0.06)\end{array}$ & $\begin{array}{l}0.12 * * \\
(0.06)\end{array}$ & $\begin{array}{c}0.06 \\
(0.055)\end{array}$ \\
\hline MEANRET & & $\begin{array}{c}0.07 * * \\
(0.03)\end{array}$ & $\begin{array}{c}0.06 * * \\
(0.03)\end{array}$ & $\begin{array}{l}0.05^{*} \\
(0.03)\end{array}$ & $\begin{array}{c}0.01 \\
(0.030)\end{array}$ \\
\hline TEST & & & & $\begin{array}{l}-0.30 \\
(0.26)\end{array}$ & $\begin{array}{l}-0.19 \\
(0.247)\end{array}$ \\
\hline Female & & & & $\begin{array}{c}0.01 \\
(0.05)\end{array}$ & $\begin{array}{c}0.01 \\
(0.046)\end{array}$ \\
\hline Age & & & & $\begin{array}{c}0.01^{* *} \\
(0.01)\end{array}$ & $\begin{array}{c}0.01 \\
(0.007)\end{array}$ \\
\hline Married & & & & $\begin{array}{c}-0.11 * * * \\
(0.03)\end{array}$ & $\begin{array}{c}-0.09 * * * \\
(0.034)\end{array}$ \\
\hline NGO college & & & & & $\begin{array}{c}0.38 * * * \\
(0.105)\end{array}$ \\
\hline DOCTOR & $\begin{array}{c}-0.10^{* *} \\
(0.04) \\
\end{array}$ & $\begin{array}{c}-0.14 * * * \\
(0.04) \\
\end{array}$ & $\begin{array}{c}-0.11 * * * \\
(0.04) \\
\end{array}$ & $\begin{array}{l}-0.06 \\
(0.06)\end{array}$ & $\begin{array}{c}0.03 \\
(0.076) \\
\end{array}$ \\
\hline Observations & 227 & 227 & 227 & 226 & 226 \\
\hline
\end{tabular}

Marginal effects reported Standard errors in parentheses; ${ }^{* * *} \mathrm{p}<0.01,{ }^{* *} \mathrm{p}<0.05,{ }^{*} \mathrm{p}<0.1$ 
Table 3:

Wages and intrinsic motivations

\section{Dependent Variable:}

Log of hourly wage

\begin{tabular}{|c|c|c|c|c|c|c|c|}
\hline & (1) & (2) & (3) & (4) & (5) & (6) & (7) \\
\hline HELPPOOR & $\begin{array}{l}-0.01 \\
(0.07)\end{array}$ & $\begin{array}{l}-0.08 \\
(0.07)\end{array}$ & $\begin{array}{l}-0.06 \\
(0.07)\end{array}$ & $\begin{array}{c}0.05 \\
(0.07)\end{array}$ & $\begin{array}{c}0.05 \\
(0.07)\end{array}$ & $\begin{array}{c}0.05 \\
(0.07)\end{array}$ & $\begin{array}{c}0.03 \\
(0.07)\end{array}$ \\
\hline MEANRET & $\begin{array}{c}0.00 \\
(0.04)\end{array}$ & $\begin{array}{l}-0.03 \\
(0.03)\end{array}$ & $\begin{array}{l}-0.03 \\
(0.03)\end{array}$ & $\begin{array}{l}-0.04 \\
(0.03)\end{array}$ & $\begin{array}{l}-0.04 \\
(0.03)\end{array}$ & $\begin{array}{l}-0.04 \\
(0.04)\end{array}$ & $\begin{array}{l}-0.05 \\
(0.04)\end{array}$ \\
\hline TEST & & $\begin{array}{l}0.61^{*} \\
(0.34)\end{array}$ & $\begin{array}{c}0.53 \\
(0.34)\end{array}$ & $\begin{array}{c}0.47 \\
(0.34)\end{array}$ & $\begin{array}{c}0.28 \\
(0.35)\end{array}$ & $\begin{array}{c}0.29 \\
(0.35)\end{array}$ & $\begin{array}{c}0.39 \\
(0.36)\end{array}$ \\
\hline NGO & & $\begin{array}{c}0.44^{* * *} \\
(0.10)\end{array}$ & $\begin{array}{c}0.45^{* * *} \\
(0.10)\end{array}$ & $\begin{array}{c}0.66^{* * *} \\
(0.22)\end{array}$ & $\begin{array}{c}0.15 \\
(0.31)\end{array}$ & $\begin{array}{c}0.13 \\
(0.35)\end{array}$ & $\begin{array}{c}0.31 \\
(0.38)\end{array}$ \\
\hline Female & & & $\begin{array}{c}-0.10 \\
(0.06)\end{array}$ & $\begin{array}{c}-0.12^{* *} \\
(0.06)\end{array}$ & $\begin{array}{c}-0.12^{* *} \\
(0.06)\end{array}$ & $\begin{array}{c}-0.12^{* *} \\
(0.06)\end{array}$ & $\begin{array}{l}-0.11^{*} \\
(0.06)\end{array}$ \\
\hline Age & & & $\begin{array}{l}-0.00 \\
(0.01)\end{array}$ & $\begin{array}{c}-0.00 \\
(0.01)\end{array}$ & $\begin{array}{c}-0.00 \\
(0.01)\end{array}$ & $\begin{array}{l}-0.00 \\
(0.01)\end{array}$ & $\begin{array}{l}-0.00 \\
(0.01)\end{array}$ \\
\hline Married & & & $\begin{array}{c}0.03 \\
(0.09)\end{array}$ & $\begin{array}{c}0.05 \\
(0.09)\end{array}$ & $\begin{array}{c}0.05 \\
(0.09)\end{array}$ & $\begin{array}{c}0.05 \\
(0.09)\end{array}$ & $\begin{array}{c}0.04 \\
(0.09)\end{array}$ \\
\hline HELPPOOR X NGO & & & & $\begin{array}{c}-0.57 * * * \\
(0.19)\end{array}$ & $\begin{array}{c}-0.52 * * * \\
(0.19)\end{array}$ & $\begin{array}{c}-0.52 * * * \\
(0.15)\end{array}$ & $\begin{array}{c}-0.48^{* * * *} \\
(0.16)\end{array}$ \\
\hline MEANRET X NGO & & & & $\begin{array}{c}0.04 \\
(0.15)\end{array}$ & $\begin{array}{c}0.02 \\
(0.14)\end{array}$ & $\begin{array}{c}0.02 \\
(0.11)\end{array}$ & $\begin{array}{c}0.05 \\
(0.11)\end{array}$ \\
\hline TEST X NGO & & & & & $\begin{array}{l}1.14^{*} \\
(0.66)\end{array}$ & $\begin{array}{l}1.17 * \\
(0.68)\end{array}$ & $\begin{array}{c}0.88 \\
(0.72)\end{array}$ \\
\hline NGO college & & & & & & $\begin{array}{c}0.03 \\
(0.09)\end{array}$ & $\begin{array}{c}0.10 \\
(0.10)\end{array}$ \\
\hline NGO college*NGO & & & & & & & $\begin{array}{c}-0.24 \\
(0.19)\end{array}$ \\
\hline DOCTOR & $\begin{array}{c}1.01^{* * *} \\
(0.06)\end{array}$ & $\begin{array}{c}0.94^{* * *} \\
(0.09)\end{array}$ & $\begin{array}{c}0.92^{* * *} \\
(0.09)\end{array}$ & $\begin{array}{c}0.93^{* * *} \\
(0.09)\end{array}$ & $\begin{array}{c}0.94^{* * *} \\
(0.09)\end{array}$ & $\begin{array}{c}0.95^{* * *} \\
(0.09)\end{array}$ & $\begin{array}{c}0.93^{* * * *} \\
(0.09)\end{array}$ \\
\hline Constant & $\begin{array}{c}4.53 * * * \\
(0.05)\end{array}$ & $\begin{array}{c}4.25 * * * \\
(0.15)\end{array}$ & $\begin{array}{c}4.41 * * * \\
(0.28)\end{array}$ & $\begin{array}{c}4.43^{* * *} \\
(0.28)\end{array}$ & $\begin{array}{c}4.50 * * * \\
(0.29)\end{array}$ & $\begin{array}{c}4.51 * * * \\
(0.27)\end{array}$ & $\begin{array}{c}4.43 * * * \\
(0.28)\end{array}$ \\
\hline Observations & 227 & 227 & 226 & 226 & 226 & 226 & 226 \\
\hline R-squared & 0.58 & 0.63 & 0.64 & 0.66 & 0.66 & 0.66 & 0.67 \\
\hline
\end{tabular}

